\title{
Effectiveness of the using moveable games, metered running, breathing exercises in the physical therapy of orphans born to HIV-infected mothers
}

\author{
Tamozhanska G.V. ${ }^{1}$, Myatyga E.M. ${ }^{1}$, Sobko I.M. ${ }^{2}$, Ulaeva L.O. ${ }^{1}$, Honcharuk N.V. ${ }^{1}$ \\ ${ }^{1}$ National university of pharmacy, Ukraine \\ ${ }^{2}$ H. S. Skovoroda Kharkiv National Pedagogical University, Ukraine
}

DOI: https://doi.org/10.34142/HSR.2020.06.04.06

\begin{abstract}
How to Cite
Tamozhanska G.V., Myatyga E.M., Sobko I.M., Ulaeva L.O., Honcharuk N.V. The effectiveness of the using moveable games, metered running, breathing exercises in the physical therapy of orphans born to HIV-infected mothers.. Health, Sport, Rehabilitation. 2020;6(4):58-69. https://doi.org/10.34142/HSR.2020.06.04.06
\end{abstract}

\begin{abstract}
Aim: to develop and experimentally substantiate the method of physical education for orphans born to HIV-infected mothers, based on the use of moveable games for the development of physical qualities, metered running, breathing exercises in orphanage conditions.

Material and methods: 28 children of 5-6 years old took part in the experiment. The experimental group included orphans born to HIV-infected mothers (14 children). The control group consisted of orphans with poor health (14 children). The research was carried out on the basis of the health care institution "Regional specialized children's home" Green Gai "for orphans and children left without parental care. The experiment lasted for 12 months, at the beginning and at the end of the experiment anthropometric studies, functional state testing (spirography, Genchi's test, Stange's test), physical fitness tests (running from a high start at 30 meters, a long jump from the spot, throwing a ball from - for the head, standing)

Results. An experimental method of physical education for orphans in an orphanage, born to HIV-infected mothers, was developed and implemented. The technique includes the use of moveable games for the development of physical qualities, dosed running exercises and complexes of respiratory gymnastics, taking into account the age characteristics of children of preschool age. A significant improvement $(p<0,05)$ in the indicators of physical development, functional state and physical fitness of children in the experimental group was shown in comparison with the control group.

Conclusions. As a result of using the proposed method, it was possible to reduce the incidence of acute respiratory infections in children born to HIV-infected mothers from 8-10 to 4-3 times a year. It has been established that the simplicity and availability of the developed methods of organizing physical education allows them to be used not only by specialists in the field of physical education of preschool children, but also by educators of preschool institutions. Key words: HIV; children; physical education; functional state; physical fitness
\end{abstract}




\section{Анотація}

Таможанська Г.В., Мятига О.М., Собко І.М., Улаєва Л.О., Гончарук Н.В. Ефективність використання рухливих ігор, дозованого бігу і дихальних вправ у фізичній терапії дітей-сиріт, народжених від ВІЛ-інфікованих матерів Мета: розробити і експериментально обґрунтувати методику фізичного виховання для дітей-сиріт, народжених від ВІЛ-інфікованих матерів, засновану на застосуванні рухливих ігор для розвитку фізичних якостей, дозованого бігу, дихальної гімнастики в умовах будинку дитини.

Матеріал і методи: в експерименті взяли участь 28 дітей 5-6 років. В експериментальну групу входили дітисироти, народжені від ВІЛ-інфікованих матерів (14 дітей). Контрольну групу склали діти-сироти з ослабленим здоров'ям (14 дітей). Дослідження проводилося на базі закладу охорони здоров'я “Обласний спеціалізований будинок дитини“ Зелений Гай "для дітей-сиріт і дітей, які залишилися без піклування батьків. Експеримент тривав 12 місяців, на початку і в кінці експерименту використовувалися антропометричні дослідження, тестування функціонального стану (спірографія, проба Генчі, проба Штанге), тестування фізичної підготовленості (біг з високого старту на 30 метрів, стрибок в довжину з місця, кидок набивного м'яча з -за голови, стоячи).

Результати: Розроблено та впроваджено до навчального процесу дитячого будинку експериментальну методику фізичного виховання для дітей-сиріт, народжених від ВІЛ-інфікованих матерів. Методика включає в себе використання рухливих ігор для розвитку фізичних якостей, бігові навантаження і комплекси дихальної гімнастики з урахуванням вікових особливостей дітей дошкільного віку. Показано достовірне $(p<0,05)$ поліпшення показників фізичного розвитку, функціонального стану і фізичної підготовленості дітей експериментальної групи в порівнянні з контрольною групою.

Висновки. Встановлено, що простота і доступність розроблених методів організації фізичного виховання дозволяє використовувати їх не тільки фахівцями в галузі фізичного виховання дітей дошкільного віку, а й вихователями дошкільних установ. В результаті використання запропонованої методики вдалося знизити у дітей, народжених від ВІЛ-інфікованих матерів, захворюваність на гострі респіраторні захворювання з 8-10 до 2-3 разів на рік.

Ключові слова: ВІЛ, діти, рухливі ігри, функціональний стан, фізична підготовленість, дихальна гімнастика.

\section{Аннотация \\ Таможанская А.В., Мятыга Е.Н., Собко И.Н., Улаева Л.А., Гончарук Н.В. Эффективность использования подвижных игр, дозированного бега и дыхательных упражнений в физической терапии детей-сирот, рожденных от ВИЧ-инфицированных матерей}

Цель: разработать и экспериментально обосновать методику физического воспитания для детей-сирот, рожденных от ВИЧ-инфицированных матерей, основанную на применении подвижных игр для развития физических качеств, дозированного бега, дыхательной гимнастики в условиях дома ребенка.

Материал и методы: в эксперименте приняли участие 28 детей 5-6 лет. В экспериментальную группу входили дети-сироты, рожденные от ВИЧ-инфицированных матерей (14 детей). Контрольную группу составили детисироты с ослабленным здоровьем (14 детей). Исследование проводилось на базе учреждения здравоохранения «Областной специализированный дом ребенка «Зеленый Гай» для детей-сирот и детей, оставшихся без попечения родителей. Эксперимент длился 12 месяцев, в начале и в конце эксперимента использовались антропометрические исследования, тестирование функционального состояния (спирография, проба Генчи, проба Штанге), тестирование физической подготовленности (бег с высокого старта на 30 метров, прыжок в длину с места, бросок набивного мяча из-за головы, стоя).

Результаты: Разработана и внедрена к учебный процесс детского дома экспериментальная методика физического воспитания для детей-сирот, рожденных от ВИч-инфицированных матерей. Методика включает в себя использование подвижных игр для развития физических качеств, беговые нагрузки и комплексы дыхательной гимнастики с учетом возрастных особенностей детей дошкольного возраста. Показано достоверное $(p<0,05)$ улучшение показателей физического развития, функционального состояния и физической подготовленности детей экспериментальной группы по сравнению с контрольной группой.

Выводы. Установлено, что простота и доступность разработанных методов организации физического воспитания позволяет использовать их не только специалистами в области физического воспитания детей дошкольного возраста, но и воспитателями дошкольных учреждений. В результате использования предложенной методики удалось снизить у детей, рожденных от ВИЧ-инфицированных матерей, заболеваемость острыми респираторными заболеваниями с 8-10 до 2-3 раз в год.

Ключевые слова: ВИЧ, дети, подвижные игры, функциональное состояние, физическая подготовленность, дыхательная гимнастика. 


\section{Introduction}

The actual problem remains building a system of physical education in an orphanage, especially among orphans born to HIV-infected mothers. HIV infection in children and adolescents is becoming relevant in many countries around the world, including Ukraine. It is known that HIV infection in children with perinatal infection occurs more rapidly and more severely than in children infected with parenteral infection. At the same time, the stage of ontogenesis at which HIV infection occurred determines the severity of clinical manifestations and the outcome of the disease [1-2]. Immunodeficiency in perinatal HIV infection increases the susceptibility of a child's body to infections: children more often suffer acute respiratory infections, they often have severe bacterial infections, with a tendency to recur and generalization, which shorten life expectancy [3-4]. An additional problem is the high proportion of children left without parental care and orphans among patients with perinatal HIV infection in Ukraine [5-6]. Thus, in the Kharkiv region, $42 \%$ of HIV-infected children are brought up in day care facilities, so the influence of maternal deprivation on their health and development cannot be ignored.

Studies shows, that the use of physical education in treatment and rehabilitation work allows us to solve not only the psychosocial problems of children with poor health, but also have a positive effect on their somatic condition [7-8].

Analysis of literature data on the study of the physical condition of children with poor health and HIV-infected children of preschool age shows that frequent acute respiratory diseases limit the motor activity of children, reduce the functionality of the respiratory and circulatory systems, slow down the growth processes and creates favorable conditions for the formation of functional posture disorders [9]. To build an effective system of physical education in preschool children, it is necessary to search for new means and methods of its organization, ways to improve the effectiveness of preventive measures that actively influence the increase in body resistance of children which is especially important for the category of children born to HIV -infected mothers. Features of the day regimen, nutrition, water treatments, hardening means, the use of physical exercises, the period and duration of sleep are the main means of forming a healthy child's body. Among physical exercises, the main means are walking, jogging, the use of various breathing exercises and hardening tools, which are highly variable in their use to increase the resistance of the child's body, are still underused [10-11]. Their use should not be carried out sporadically in the form of periodic physical training, but continuously throughout the day. It is logical to assume that the use of moveable games, dosed running, breathing exercises in the physical education of children in this category will improve their physical condition and improve their health [12].

In this regard, the purpose of our research was the development and experimental substantiation of physical education methods for orphans born to HIV-infected mothers, based on the use of metered running, breathing exercises and outdoor games for the development of motor skills in the conditions of an orphanage.

\section{Matherials and methods}

\section{Participants}

The experiment involved 28 orphans of preschool age (5-6 years). The experimental group included orphans born to HIV-infected mothers (14 children). The control group consisted of children with poor health (14 children), left without parental care. Children with poor health have acute respiratory infections and acute respiratory viral infectious diseases 8-10 times a year. Groups of children were homogeneous by sex and age.

\section{Procedure}

Determination of the level of physical development.

Anthropometric methods included measurements of, body weight, and girths of various body parts. Hand strength measured on the right and with the left hand, using a dynamometer, standing in the starting position with the arm extended downwards. The anthropometric examination of children 6 years was carried out by standard equipment according to generally accepted and unified techniques.

Determination of the physical preparedness level.

Control tests of physical fitness were carried out by the estimation of level of development of certain motor qualities. The rate of strength was determined by the results of the Throw stuffed ball (1 $\mathrm{kg}$ ) from behind the head, standing. Speed characteristics were determined by the results of running $30 \mathrm{~m}$ sprint run. Speed-strength qualities were determined by the results of a standing long jump. The starting position - standing position, legs are abducted on the width of the shoulders, the result 
was measured in centimeters with an accuracy of 1 $\mathrm{cm}$

Determining the level of functionality.

To assess the state of the function of external respiration, spirography was carried out - a graphic recording of the parameters of the function of external respiration. A spirographic study was conducted with the help of specialists from the Scientific and Research Institute for the Health of Children and Adolescents (Department of Functional Diagnostics). Spirograms were recorded on a Spirograph SP100 (Contec Medical Systems Co., China) after a 15-minute rest in the supine position on a couch. When conducting a spirographic study, only those indicators of respiratory function were selected that can be used as criteria for physical abilities when comparing them with the data of the clinical condition, the magnitude of aerobic capacity and tolerance to physical activity: respiratory rate (RR), depth of respiration, or respiratory volume $(\mathrm{RV})$, minute volume of respiration (MVR), vital capacity of lungs (VC), maximum ventilation of the lungs (MVL), coefficient oxygen utilization in the lungs (COU2). Functional tests were also used: the Shtange test - after 5 minutes of rest, the recipient takes a maximum breath, then exhalation, incomplete inhalation ( $75 \%$ of maximum), holds his breath with a closed nose and mouth; the Genchi test is performed similarly, only holding of the breath is made after a full exhalation.
The study was conducted on the basis of the Municipal Healthcare Institution "Regional Specialized Orphanage" Green Grove "for orphans and children left without parental care. Throughout the entire time of stay of children in this institution, a comprehensive installation treatment is carried out, which includes not only drug treatment, but also physiotherapy, therapeutic physical culture, massage, psychological and pedagogical correction.

The experiment lasted from September 2019 to September 2020. Before and after the experiment, the control and experimental group were tested in physical development, physical fitness and functionality of organism.

The children of the control group did physical exercises according to the program, which includes general developmental and corrective exercises. Length of lessons from 10-12 to 30 minutes 3 times a week. Children in the control group performed physical exercises according to the program, which includes:

- general developmental exercises;

- corrective exercises;

- simple exercises in balance (for example, walking and running between two parallel lines drawn at a distance of $20-25 \mathrm{~cm}$ from each other, on a bench height of $15-20 \mathrm{~cm}$ );

- gymnastic exercises with objects (balls, hoops, sticks).

The experimental group applied the proposed experimental method of physical education. (Fig. 1).

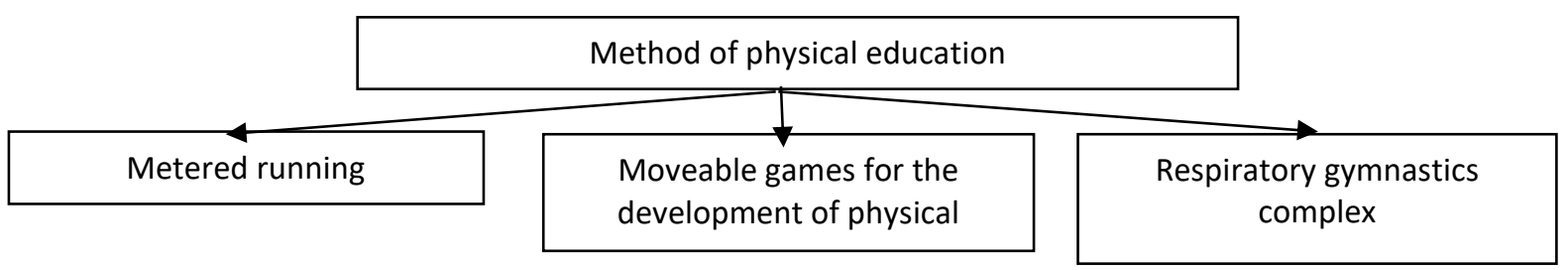

Fig. 1. Method of physical education

Length of lessons from 10-12 to 30 minutes. In the weekly cycle, dosed-run exercises were held 3 times in combination with a complex of breathing exercises and active games were held 3 times in combination with a complex of breathing exercises.

At the first stage, lasting 2 months, training was conducted on the technique of running. The duration of running in children was 20 seconds at a pace of 70 steps per minute. Every 2 classes the duration of the run increased by 10 seconds. At the second stage, the race load was increased - the duration of the run increased by 15 seconds after each session. By the end of the stage, the duration of which was 4 months, the duration of the run increased to 34 minutes. The third stage, lasting for 2 months, was characterized by stabilization of the duration of the race load, during which only its variation changed continuous running alternated with relay and interval runs. At stage IV, there was a decrease in running load.

In the selection of mobile games for the development of physical qualities, the age and physical fitness of children in this category were taken into account.

The moveable game for the development of power, "Who is stronger?"

Action: the game is played in pairs. Players occupy positions on opposite sides of the middle line. The players' task is to drag the opponent's hands on their side. The player who steps behind the opponent's line loses (Fig. 2). 


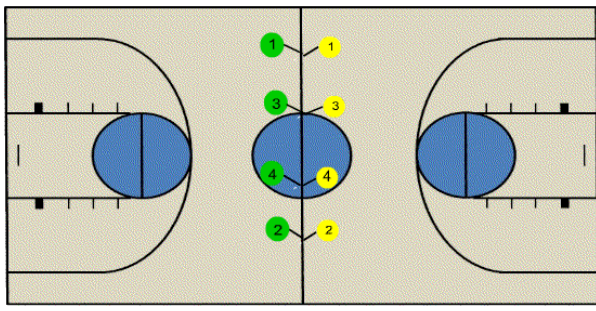

Fig. 2. The illustration to the moveable game "Who's stronger?"

The moveable game for the development of agility "Quick hoop"

Inventory: hoops, racks. Course of the game: two teams play, which line up in a column one by one in front of the start line. At 10-15 m against each column indicate the place of rotation (rack). The first player holds a hoop. At the signal, he moves to the place of rotation and rolls the hoop on the floor, then goes around the rack and turns, rotating the hoop on the belt. At the start line, the first player passes the hoop to the second and so on. Wins the team that performs the task first (Fig. 3).


Fig. 3. Moveable game for the development of speed "Quick hoop"

The moveable game for the development of speed "Who is faster?"

Inventory: tennis balls, hoops. Course of the game: they put a hoop on the floor, into which they put tennis balls, at a distance of $15 \mathrm{~m}$ they put two more hoops, in which the teams are lined up. At the signal of the teacher, the players take turns running to the balls and begin to carry them each into their own hoop. If a player drops the ball, he must pick it up and put it in a hoop. Wins the team that quickly moved all the balls in their hoop (Fig. 4).

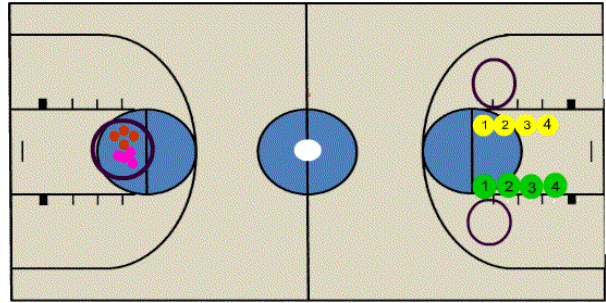

Fig. 4. The illustration to the moveable game "Who is faster?"

Moveable game for the development of endurance "Cross in a circle"

Inventory: racks. Course of the game: 4 racks are placed on the court so that players, running around them, move along a rectangle. The distance between the posts is 15-20 m (long sides of the rectangle) and 8-10 m (short sides). The game involves two teams of 4 children, which are evenly spaced around the perimeter of the rectangle one after another. At the command of the players begin to run counterclockwise, bending around the rack. The task of each is to tag the player of another team. The signal for the end of the game is given when 3 people from the team are tagged (Fig. 5).

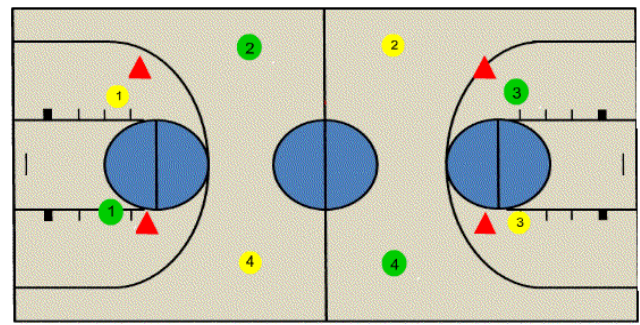

Fig. 5. The illustration to the moveable game "Cross in a circle"

A large number of special breathing exercises were used in the experimental group. The basis of the breathing exercises is an exercise with an extended and strengthened exhalation against the background of general strengthening and general developing physical exercises. This was achieved by pronouncing vowel sounds (aaa, ooh, oh-oh-oh) sizzling consonants ( $\mathrm{j}$ and $\mathrm{sh}$ ) and combinations of sounds (oh, ooh, fu). These breathing exercises were conducted in the form of a game (a bee is buzzing, an airplane is buzzing, train wheels are knocking, etc.).

Respiratory gymnastics complex:

1. "Throw the ball." Children are in the circle. One of them holds the ball in his raised hands. Inhales, and on the exhale, throws the ball to his friend, uttering a long "uuh".

2. "Dragon". Children alternately breathe through each nostril. They need to pinch one nostril with your finger, and the second inhale very deeply and exhale air

3. "As the crow says." The children spread their legs shoulder-width apart, their arms lowered down. While inhaling, you need to separate your arms to the sides, like wings of a crow, and while exhaling, slowly lower your arms, saying "kaarrr". Demand from children that they maximally stretch the sound "r".

4. "Insatiable Hamster." Children should inflate their cheeks and walk slowly in a circle. Next you need to slap on the cheeks, releasing the air. Then walk a couple of steps, breathing well with your nose, like a hamster that sniffs out food to fill your cheeks again. 
5. "Watches" I.P. - standing, legs slightly apart, hands lowered. Swinging your arms straight back and forth, say "Tick-Tac"

6. "Trumpeter" I.P. - sitting on a chair, hands clenched and raised up. Slow exhalation with a loud pronunciation of the sound "fffff"

7. "Rooster" I. P. - stand up straight, legs together, hands to the sides. Slam your hands on the thighs and, exhaling, say "Cock-A-Doodle-Doo!"

8. "The locomotive" I. P. - arms bent at the elbows. Walking around the room, rotating bent arms along the body, hands clenched into fists and sentence "Chu - Chu - Chu"

9. "Pump" I.P. - stand up straight, legs together, arms along the body. Lean forward with the pronunciation of the sound "s-s-s"

Statistical methods.

The digital material obtained during the research was processed using traditional methods of mathematical statistics. For each indicator, the arithmetic mean value of $\mathrm{X}$, the standard deviation $\mathrm{S}$ (standard deviation), the assessment of the significance of differences between the parameters of the initial and final results, as well as between the control and experimental groups by the Student t-test with the corresponding significance level (p) were determined. Mathematical data processing was carried out with the help of Microsoft Excel Analysis Data Analysis Software, SPSS. Differences were considered significant at a significance level of $p$ $<0.05$.

\section{Results}

When studying the indicators of the physical development of the examined children, the data we obtained characterize the lag of the children of the experimental group in almost all indicators from the children of the control group. Analysis of the initial examination of children of both groups showed that of all indicators of physical development only age indicators of children in the control group correspond, and in children of the main group, the above indicators tend to decrease significantly and significantly differ $(p<0.05)$ from those of children with weakened health (table 1).

Table 1

Indicators of the physical development of children in the experimental and control groups during the initial examination

\begin{tabular}{|c|c|c|c|c|c|c|c|}
\hline \multirow{2}{*}{ № } & \multirow{2}{*}{ Indicators } & \multicolumn{2}{|c|}{ Experimental group $(n=14)$} & \multicolumn{2}{|c|}{ Control group $(n=14)$} & \multirow[b]{2}{*}{$\mathrm{t}$} & \multirow{2}{*}{$\mathrm{p}$} \\
\hline & & $X \pm m$ & $S$ & $X \pm m$ & $\mathrm{~S}$ & & \\
\hline 1 & Height, sM & $110.23 \pm 1.67$ & 6.46 & $116.0 \pm 0.60$ & 1.27 & 3.27 & $<0.05$ \\
\hline 2 & Weight, kg & $19.38 \pm 0.56$ & 2.18 & $22.81 \pm 0.87$ & 3.37 & -3.19 & $<0.05$ \\
\hline \multirow[t]{2}{*}{3} & $\begin{array}{l}\text { Wrist } \\
\text { dynamometry, } \mathrm{kg} \text {, } \\
\text { right hand }\end{array}$ & $6.20 \pm 0.52$ & 2.02 & $7.26 \pm 0.53$ & 2.09 & 1.36 & $>0.05$ \\
\hline & left hand & $5.71 \pm 0.63$ & 2.44 & $6.98 \pm 0.59$ & 2.28 & 1.42 & $>0.05$ \\
\hline 4 & VC in lungs & $1.04 \pm 0.04$ & 0.16 & $1.22 \pm 0.02$ & 0.09 & 4.07 & $<0.05$ \\
\hline
\end{tabular}

During the initial examination of children in the experimental and control groups, significant

differences were observed in terms of external respiration function (table 2).

Table 2

Indicators of respiratory function during the initial examination of children of the experimental and control groups

\begin{tabular}{|c|c|c|c|c|c|c|}
\hline \multirow{2}{*}{ Indicators } & \multicolumn{2}{|c|}{ Experimental group, $n=14$} & \multicolumn{2}{|c|}{ Control group, n=14 } & \multirow[b]{2}{*}{$\mathrm{t}$} & \multirow[b]{2}{*}{$p$} \\
\hline & $X \pm m$ & $S$ & $X \pm m$ & $\mathrm{~S}$ & & \\
\hline $\mathrm{RR}, \mathrm{rmpm}$ & $25.78 \pm 0.51$ & 1.92 & $24.14 \pm 0.29$ & 1.09 & 2.77 & $<0.05$ \\
\hline $\mathrm{RV}, \mathrm{ml}$ & $121.13 \pm 2.73$ & 10.59 & $144.53 \pm 5.72$ & 22.16 & 3.56 & $<0.01$ \\
\hline MVR, Ipm & $3.12 \pm 0.09$ & 0.35 & $3.31 \pm 0.08$ & 0.33 & 1.47 & $>0.05$ \\
\hline MVL pm & $23.42 \pm 0.62$ & 2.41 & $28.45 \pm 1.01$ & 3.92 & 2.98 & $<0.05$ \\
\hline $\mathrm{COU}_{2} \mathrm{mlpm}$ & $29.50 \pm 0.53$ & 6.22 & $35.76 \pm 0.58$ & 5.24 & -2.87 & $<0.05$ \\
\hline Stange's test, s & $16.13 \pm 1.04$ & 4.05 & $19.86 \pm 0.73$ & 2.85 & 2.81 & $<0.05$ \\
\hline Gencha's test, s & $9.46 \pm 0.56$ & 2.19 & $12.0 \pm 0.85$ & 3.31 & 2.39 & $<0.05$ \\
\hline
\end{tabular}

A comparative analysis of the indicators of the development of physical qualities is presented in 
table 3. The decline in the indicators of the development of the physical qualities of children, which constituted the experimental group, was the result of poor physical development and a significant decrease in the children's physical activity.

Indicators of the development of physical qualities of children experimental

Table 3 and control groups during the initial examination

\begin{tabular}{lcccccc}
\hline \multirow{2}{*}{ Indicators } & \multicolumn{2}{c}{ Experimental group $(\mathrm{n}=14)$} & \multicolumn{2}{c}{ Control group $(\mathrm{n}=14)$} & $\mathrm{t}$ & $\mathrm{p}$ \\
\cline { 2 - 5 } & $\mathrm{X} \pm \mathrm{m}$ & $\mathrm{S}$ & $\mathrm{X} \pm \mathrm{m}$ & $\mathrm{S}$ & & \\
\cline { 2 - 5 } $\begin{array}{l}\text { Running from a high start at } \\
30 \text { meters }\end{array}$ & $8.46 \pm 0.06$ & 0.23 & $8.28 \pm 0.04$ & 0.19 & 2.25 & $<0.05$ \\
\hline Long jump from stand, sm & $84.33 \pm 0.70$ & 2.74 & $86.86 \pm 0.35$ & 1.35 & -3.09 & $<0.05$ \\
\hline $\begin{array}{l}\text { Throw stuffed ball (1kg) from } \\
\text { behind the head, standing, } \mathrm{m}\end{array}$ & $1.41 \pm 0.04$ & 0.17 & $1.58 \pm 0.04$ & 0.18 & 2.56 & $<0.05$ \\
\hline
\end{tabular}

Analysis of the results of the initial examination of children of both groups showed that according to physical development data, only indicators of children of the control group correspond to age standards, and in children of the experimental group, the obtained indicators tend to significantly decrease and significantly differ from the values of children with impaired health.

In the second study, in children of the experimental and control groups, there was a general tendency to increase in height - weight indicators (table 4).

Dynamics of indicators of physical development of children in the experimental and control groups with re-examination

\begin{tabular}{|c|c|c|c|c|c|c|c|}
\hline \multirow{2}{*}{ № } & \multirow{2}{*}{ Indicators } & \multicolumn{2}{|c|}{ Experimental group $(n=14)$} & \multicolumn{2}{|c|}{ Control group $(n=14)$} & \multirow{2}{*}{$\mathrm{t}$} & \multirow{2}{*}{$\mathrm{p}$} \\
\hline & & $X \pm m$ & $S$ & $X \pm m$ & $\mathrm{~S}$ & & \\
\hline 1 & Height, SM & $115.80 \pm 1.55$ & 60.1 & $120.0 \pm 1.24$ & 4.82 & 1.95 & $>0.05$ \\
\hline 2 & Weight, kg & $24.16 \pm 0.49$ & 1.90 & $25.84 \pm 0.89$ & 3.46 & 1.59 & $>0.05$ \\
\hline \multirow[t]{2}{*}{3} & $\begin{array}{l}\text { Wrist } \\
\text { dynamometry, kg, } \\
\text { right hand }\end{array}$ & $9.33 \pm 0.47$ & 1.85 & $9.89 \pm 0.48$ & 1.87 & 0.79 & $>0.05$ \\
\hline & left hand & $8.48 \pm 0.51$ & 2.01 & $9.84 \pm 0.54$ & 2.11 & 1.74 & $>0.05$ \\
\hline 4 & VC in lungs & $1.47 \pm 0.03$ & 0.14 & $1.53 \pm 0.02$ & 0.10 & 1.30 & $>0.05$ \\
\hline
\end{tabular}

In children of the experimental and control groups, there were no significant differences in the reexamination in terms of the chest circumference and the magnitude of the chest excursion. The fact of a significant increase in chest excursion rates in children of the experimental group is explained by the good mobility of the chest. There was a significant increase in lung capacity, both in experimental and in control group children.

Comparative analysis of the functional state of the cardiovascular system during the reexamination of children of the main and control groups is presented in Table 6. When assessing the functional state of the cardiovascular system, according to the heart rate, in both groups, no significant differences were observed ( $p>0,05)$. With repeated analysis of respiratory function, there was a marked improvement and development by economism of the activity of the respiratory system (table 5).

Table 5

Dynamics of indicators function during repeated examination of children of the main and control groups

\begin{tabular}{lllllll}
\hline \multirow{2}{*}{ Indicators } & \multicolumn{2}{c}{ Experimental group, $\mathrm{n}=14$} & \multicolumn{2}{l}{ Control group, $\mathrm{n}=14$} \\
\cline { 2 - 8 } & \multicolumn{1}{c}{$\mathrm{X} \pm \mathrm{m}$} & $\mathrm{S}$ & $\mathrm{X} \pm \mathrm{m}$ & $\mathrm{S}$ & $\mathrm{t}$ & $\mathrm{p}$ \\
\hline $\mathrm{RR}, \mathrm{rmpm}$ & $22.0 \pm 0.18$ & 0.67 & $21.92 \pm 0.22$ & 0.82 & 0.28 & $>0.05$ \\
\hline $\mathrm{RV}, \mathrm{ml}$ & $170.46 \pm 3.42$ & 13.27 & $171.0 \pm 6.08$ & 23.53 & 0.07 & $>0.05$ \\
\hline
\end{tabular}




\begin{tabular}{lllllll}
\hline \hline $\mathrm{MVR}, \mathrm{Ipm}$ & $3.74 \pm 0.07$ & 0.28 & $3.59 \pm 0.17$ & 0.29 & 1.39 & $>0.05$ \\
\hline $\mathrm{MVL} \mathrm{pm}$ & $38.24 \pm 0.67$ & 2.59 & $38.68 \pm 0.78$ & 30.4 & 0.41 & $>0.05$ \\
\hline $\mathrm{COU}_{2} \mathrm{mlpm}$ & $36.35 \pm 0.68$ & 2.65 & $36.85 \pm 0.37$ & 1.44 & 0.62 & $>0.05$ \\
\hline Stange's test, $\mathrm{s}$ & $24.86 \pm 0.89$ & 3.46 & $25.13 \pm 0.93$ & 3.60 & 0.20 & $>0.05$ \\
\hline Gencha's test, $\mathrm{s}$ & $18.33 \pm 0.93$ & 3.61 & $17.73 \pm 1.07$ & 4.18 & 0.40 & $>0.05$ \\
\hline
\end{tabular}

Comparative analysis of indicators of the development of physical qualities, according to Table 6 , after the application of the running program, showed a significant improvement in the results in the development of physical qualities in relation to primary research.

Table 6

Indicators of the development of physical qualities of children experimental and control groups with re-examination

\begin{tabular}{lcccccc}
\hline \multirow{2}{*}{ Indicators } & \multicolumn{2}{c}{ Experimental group $(\mathrm{n}=14)$} & \multicolumn{2}{c}{ Control group $(\mathrm{n}=14)$} & \multirow{2}{*}{$\mathrm{t}$} & $\mathrm{p}$ \\
\cline { 2 - 5 } & $\mathrm{X} \pm \mathrm{m}$ & $\mathrm{S}$ & $\mathrm{X} \pm \mathrm{m}$ & $\mathrm{S}$ & & \\
\hline $\begin{array}{l}\text { Running from a high start at } \\
30 \text { meters }\end{array}$ & $8.10 \pm 0.04$ & 0.16 & $7.99 \pm 0.03$ & 0.12 & 2.05 & $<0.05$ \\
\hline Long jump from stand, sm & $97.46 \pm 0.97$ & 3.77 & $96.93 \pm 1.03$ & 4.02 & 0.35 & $>0.05$ \\
\hline $\begin{array}{l}\text { Throw stuffed ball (1kg) from } \\
\text { behind the head, standing, } \mathrm{m}\end{array}$ & $1.81 \pm 0.02$ & 0.08 & $1.87 \pm 0.02$ & 0.09 & 1.86 & $>0.05$ \\
\hline
\end{tabular}

A comparative analysis of the reexamination of children of both groups showed that the consistent use of outdoor games, metered running in combination with breathing exercises favorably affects the state of physical development of children, especially the experimental group, since all these indicators approach the values of children with impaired health.

\section{Discussion}

Modern scientists [15-17] actively apply multivariate analysis methods to study the structure of the integrated fitness of young and skilled athletes in various sports. Leading Ukrainian specialists [18] consider factor analysis to be the most appropriate mathematical tool. It allows you to reduce a wide range of indicators of preparedness and to identify the main components that determine the exact characteristics of the individual characteristics of athletes. The use of modern methods of analysis helps to create optimal training methods that best meet the requirements of the training process in a specific period of time. In sports games, using factor analysis, scientists [19] develop individual factor models of physical fitness of athletes of various game roles. In this regard, the studies conducted in this work confirm and supplement the data of the listed authors about the need to use a wide range of physical and technical readiness indicators to determine the factor structure of preparedness of archery shooters aged $14-15$ years.
Sport experts emphasize that sporting achievements in archery are determined by the level of technical readiness of an athlete, because the strength of the shooter is characterized by the degree of quality of the motor actions on the basis of which the archery technique is performed [20-21]. One of the main indicators of technical excellence are efficiency and cost-effectiveness of actions. No less important are the indicators of accuracy and reliability that ensure the sustainability of the sporting result. In turn, the improvement of sports equipment will be fruitful and effective only if it provides for the formation of a biomechanically rational structure of movements, in accordance with the actual level of physical fitness of an athlete. After all, archery in competitive conditions requires the athlete to repeatedly use muscular efforts in static, overcoming and progressive modes and provide stretching of the bow (15-25 kg), holding the pose at the time of aiming (up to $10 \mathrm{~s}$ ). In this study, the indicators of physical and technical readiness of young archers in the process of learning motor actions are analyzed. The data obtained emphasize the importance of the level of development of static and dynamic strength endurance, coordination of movements in the process of improving the sports and technical skills of athletes at the stage of special basic training. At this stage, to a greater extent than at previous ones, technical improvement is based on various rifle exercises. For example, shooting with different time intervals reached the arrows and the shot as a whole, without visual control, etc. As a result of the work on this and subsequent stages of 
many years of training, the archer must master the technique of many special preparatory exercises quite well. This approach forms his ability to quickly master the technique of shooting an Olympic bow, which corresponds to his morphofunctional capabilities, and further provides the shooter with the ability to vary the basic parameters of technical skill depending on the conditions of specific competitions [2-22]. Thus, during this period, the focus should be on the development of static strength endurance, which provides for a long and repeated repetition of the posture on the alert and maintain it for a certain time, these actions are aimed at adapting the archer's body to specific loads. The optimal distribution of the efforts of all muscle groups involved in the implementation of an aimed shot is largely dependent on the level of development of dynamic strength endurance. Therefore, the development of this quality should be aimed at ensuring coordinated actions of numerous muscle groups of the back, arm, which directly performs the tension of the bow and arm, which provides the content of the bow and counteracts its pressure. The development of coordination abilities lays the foundation for the further development of accurate perception and reproduction of muscular efforts, as well as the ability to differentiate temporal, velocity, and power characteristics in combination of movements provide a shot. Therefore, it is necessary to develop the ability to effectively manage muscle tension and relaxation [22]. The manifestation of power abilities is closely related to the efficiency of the energy supply of the respective work, the level of development of speed abilities and flexibility, they are necessary for keeping the bow and resistance to its pressure, as well as for stretching the bow, so special strength is developed regarding the archer's technical actions.

The results of the study determine the main directions of physical training of archers from the bow of 14-15 years old, specializing in the Olympic bow. To optimize the training process of athletes of this age category, optimal tools, forms and methods of training athletes were selected. For the development and improvement of static power endurance, the use of the method of strictly regulated exercises with the use of special schemes, providing for a long bow holding and tight rest intervals, has been proposed. For the development of dynamic strength endurance, it is recommended to perform multiple imitations of bow tension with a resistance of $25-50 \%$ of the maximum force at an average pace until complete fatigue (work on a simulator with the exception of a hand holding a bow, or with a rubber band) $60-70 \%$ of maximum effort at an average pace. Special dexterity should be developed with the help of exercises characteristic of the activity of the archery bow. When training coordination abilities, it should be taken into account that the archer simultaneously performs several technical actions that require coherence in the work of various muscle groups (bow holding, resistance to bow pressure, bow tension and orientation in the shooting plane, maintaining the necessary posture, correct brush position, which ensures release of a bowstring), and corrects various characteristics of his movements, agreeing with changes in the situation. In this regard, modeling the complicated conditions of activity in the process of shooting (reducing the time allotted for shooting, changing light, shooting in adverse meteorological conditions, etc.), which cause the archer to change the pace and rhythm of shooting, take into account the influence of artificially introduced obstacles and look for new ways to overcome the difficulties. For the development and improvement of speed capabilities, it is recommended to perform multiple repetitions of speed actions with maximum or maximum intensity on stimulus signals with a gradual reduction in response time without disrupting the execution technique. Exercises related to the imitation of individual elements of a shot with an arrow can be used, or directly shooting at various distances with specific tasks. For the development of strength, exercises with weights, exercises using various training devices and exercises that are performed at a slow pace with significant muscle tension are proposed.

Thus, regular monitoring and accounting of the dynamics of physical and technical readiness, proper selection of means and methods of sports training will optimize the training process of the archers at different stages of many years of training and adjust it when changing any training conditions (changes in the competition calendar, injuries, diseases and etc.).

\section{Conclusion}

It is shown that the indicators of complex testing of archers from 14 to 15 years old, specializing in Olympic bow, are divided into five factors: static power endurance, dynamic power endurance, coordination capabilities, speed capabilities, strength capabilities. It was revealed that the first, the most important factor, included shooting indicators in the open air and indicators of the static power endurance of the archer, the second included shooting indicators in the room and indicators of the dynamic power endurance of the archer, which indicates the dependence of physical and technical 
training in archery. The use of rational means and methods of physical and technical training of archers on the stage of special basic training for the optimal construction of the training process of athletes is recommended.

\section{Acknowledgments}

The study was conducted according to: research work, which is funded by the state budget of the Ministry of Education and Science of Ukraine for 2017-2018: "Theoretical and methodological foundations of the application of integrated

\section{References}

1. Vinogradsky BA. Sports archery: fundamentals and improvements of special preparedness. Monograph: LDUFK;2012.

2. Symanovich PG. Means and methods of integrated control young archers. Pedagogics, psychology, medical-biological problems of physical training and sports. 2005;4:82-88.

3. Antonov SV, Pityn MP. Effectiveness of qualified riflemen archery in control exercises with difficult conditions performance. Pedagogics, psychology, medical-biological problems of physical training and sports. 2011;9:8-10.

4. Artiuh, V, Kozina Z, Koval V, Safronov D, Fomin S, Novikov Y. Influence of application of special means of development of equilibrium and precision-target movements on the level and structure of psychophysiological indicators, physical and technical readiness of archers. Health, Sport, Rehabilitation. 2019;4(4):7-16. doi:http://dx.doi.org/10.5281/zenodo.2536441.

5. Lankford DE, Higginson B. The effect of fatigue and elevated heart rate on archery shot performance. Medicine and Science in Sports and Exercise. 2016;48(5):858-858. doi:10.1249/01.mss.0000487571.81523.18

6. Lantz K, Webste J, Krueger J. The effects of monocular versus binocular aiming on archery performance. Investigative ophthalmology \& visual science. 2018;59(9):2962-2967.

7. Tarasova LV, Mankhanov ZS. Special performance of highly qualified arrow arrows. Theory and methods of high performance sport. 2014;9:44-46.

8. Korobeinikova EY, Leonov SV, Polikanova IS. Psychological features of attention in archery. National Psychological Journal. 2017;2:35-45. doi: 10.11621/npj.2017.0205. technologies for self-improvement, harmonious physical, intellectual and spiritual development and the formation of a healthy lifestyle for people of different age and social groups, including athletes and people with special needs" (State Registration No: 0119U100616).

\section{Conflict of interest}

The authors declare that there is no conflict of interest.

9. Ariffin MS, Rambely AS, Ariff NM. Wrist muscle activity of khatrah approach in mameluke technique using traditional bow archery. UniversityKebangsaan-Malaysia, Faculty-of-Science-andTechnology (UKM FST) Postgraduate Colloquium. Univ Kebangsaan Malaysia, Fac Sci \& Technol, Selangor. 2018;1940:12-13.

10. Simsek D, Cerrah AO, Ertan HA. Comparison of the ground reaction forces of archers with different levels of expertise during the arrow shooting. Science \& sports. 2019;34(2):137-145.

11. Taha Z, Musa RM, Majeed PP. The identification of high potential archers based on fitness and motor ability variables: A Support Vector Machine approach. Human movement science. 2018;57:184193.

12. Shinohara H, Urabe Y. Analysis of muscular activity in archery: a comparison of skill level. Journal of sports medicine and physical fitness. 2018;58(12):1752-1758.

13. Muazu MR, Majeed AP, Abdul T, Zahari T, Siow WC. A machine learning approach of predicting high potential archers by means of physical fitness indicators. S. PLoS ONE. 2019;14(1):e0209638.

14. doi.org/10.1371/journal.pone.0209638

15. Nabavinik M, Abaszadeh A, Mehranmanesh M. Especial skills in experienced archers. Journal of motor behavior. 2018;50(3):249-253.

16. Sobko IN, Ulaeva LA, Yakovenko YA. Factorial structure of physical rehabilitation group students' complex fitness. Physical education of students. 2016;20(2):32-37.

17. Shepelenko T, Kozina Z, Cieślicka M, Prusik K, Muszkieta R, Sobko I, Ryepko O, Bazilyuk T, Polishchuk S, Osiptsov A, Kostiukevych V. Factor structure of aerobics athletes preparation. Pedagogics, psychology, medical-biological problems of physical training and sports. 2017;21(6):345-352. 
18. Kozina ZhL, Cieslicka M, Prusik K, Muszkieta R, Sobko IN, Ryepko OA, Bazilyuk TA, Polishchuk SB, Osiptsov AV, Korol SA. Algorithm of athletes' fitness structure individual features' determination with the help of multidimensional analysis (on example of basketball). Physical education of students. 2017;21(5):225-238.

19. Kozina Z, Bazilyuk T, Boyko A. Analysis of the structure of the integrated preparedness of qualified handball players using the methods of multivariate analysis. Health, sport, rehabilitation. 2017;3(2):1524. doi: http: //dx.doi.org/10.34142/zenodo.1109904.

20. Kozina Z, Khrapov S, Yevstratov S, Kolomiets N, Hryshchenko S, Minenok A, Nosko I. Individual factor structure of qualified volleyball players' preparedness. Health, sport, rehabilitation.
2019;5(1):56-65

doi:http://dx.doi.org/10.34142/HSR.2019.05.01.06

21. Baydychenko TV, Arkhipova EA, Shakirov RV. Improving the technical performance of the athletes, classic bow shooters. Scholarly notes. 2014;3(109):19-25. DOI: 10.5930/issn.19944683.2014.03.109.p19-25

22. Gonzalez CC, Causer J, Grey MJ. Exploring the quiet eye in archery using field- and laboratory-based tasks. Experimental brain research. 2017;235(9):2843-2855

23. Simsek D, Cerrah AO, Ertan H. Muscular coordination of movements associated with arrow release in archery. South african journal for research in sport physical education and recreation. 2018;40(1):141-155.

\section{Information about the authors}

Tamozhanskaya A.V.

https://orcid.org/0000-0003-2430-8467

kulichka79@ukr.net

National University of Pharmacy;

61002, Kharkiv, st. Pushkinskaya, 53, Kharkov, Ukraine

\section{Myatyga E.N.}

https://orcid.org/0000-0002-5258-3442

olenam2013@yandex.ua

National University of Pharmacy;

61002, Kharkiv, st. Pushkinskaya, 53, Kharkov, Ukraine

\section{Sobko I.N.}

http://orcid.org/0000-0001-5588-4825

sobko.iryna18@gmail.com

H. S. Skovoroda Kharkiv National Pedagogical University

Alchevskikh st. 29, Kharkiv, 61002, Ukraine

\section{Ulaeva L.A.}

http://orcid.org/0000-0003-0468-756X;

lorik2340@gmail.com;

National University of Pharmacy;

61002, Kharkiv, st. Pushkinskaya, 53, Kharkov, Ukraine

\section{Honcharuk N.V.}

https://orcid.org/0000-0002-1206-5974

goncharuknatalyaa@gmail.com

National University of Pharmacy;

61002, Kharkiv, st. Pushkinskaya, 53, Kharkov, Ukraine

\section{Інформація про авторів}

Таможанская А.B.

https://orcid.org/0000-0003-2430-8467

kulichka79@ukr.net

Національний фармацевтичний університет;

61002, вул. Пушкінська 53, Харків, 61002, Україна 


\section{Мятига Е.H.}

https://orcid.org/0000-0002-5258-3442

olenam2013@yandex.ua

Національний фармацевтичний університет;

61002, вул. Пушкінська 53, Харків, 61002, Україна

\section{Собко I.М.}

http://orcid.org/0000-0002-4920-9775

sobko.iryna18@gmail.com

Харківський національний педагогічний університет імені Г.С. Сковороди, вул. Алчевських 29, Харків, 61002, Україна

\section{Улаєва Л.А.}

http://orcid.org/0000-0003-0468-756X;

lorik2340@gmail.com;

Національний фармацевтичний університет;

61002, вул. Пушкінська 53, Харків, 61002, Україна

\section{Гончарук Н.В.}

https://orcid.org/0000-0002-1206-5974

goncharuknatalyaa@gmail.com

Національний фармацевтичний університет;

61002, вул. Пушкінська 53, Харків, 61002, Україна

\section{Информация об авторах}

\section{Таможанская А.B.}

https://orcid.org/0000-0003-2430-8467

kulichka79@ukr.net

Национальный фармацевтический университет;

61002, ул. Пушкинская 53, Харьков, 61002, Украина.

\section{Мятыга Е.H.}

https://orcid.org/0000-0002-5258-3442

olenam2013@yandex.ua

Национальный фармацевтический университет;

61002, ул. Пушкинская 53, Харьков, 61002, Украина

\section{Собко И.Н.}

http://orcid.org/0000-0002-4920-9775

sobko.iryna18@gmail.com

Харьковский национальный педагогический университет имени Г.С. Сковороды, ул. Алчевских 29, Харьков, 61002, Украина

\section{Улаева Л.А.}

http://orcid.org/0000-0003-0468-756X;

lorik2340@gmail.com;

Национальный фармацевтический университет;

61002, ул. Пушкинская 53, Харьков, 61002, Украина

\section{Гончарук Н.В.}

https://orcid.org/0000-0002-1206-5974

goncharuknatalyaa@gmail.com

Национальный фармацевтический университет;

61002, ул. Пушкинская 53, Харьков, 61002, Украина

This work is licensed under a Creative Commons Attribution 4.0 International License (CC BY 4.0)

Received: 2020-09-17 Accepted: 2020-10-12 Published: 2020-12-20

